\title{
Examination of Pre-service Teachers' Interpretation Case of Fossil Words in Turkish Reduplications/Idioms
}

\section{Bekir Direkci}

Assoc. Prof., Akdeniz University, Turkey, bdirekci@akdeniz.edu.tr

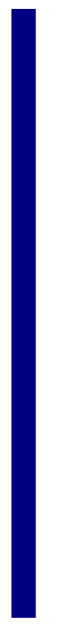

\begin{abstract}
Idioms and reduplications which have a significant place in the elements of vocabulary represent the characteristics of the society they come to light. Therefore, the words carried by these stereotyped phrases from past to the present, come out as the best way of expressing the feelings, senses, and existence of the society. This study aimed at ascertaining the pre-service Turkish language teachers' interpretation case of fossil words in Turkish reduplications and idioms. It adopts the concurrent triangulation design of mixed methods research. "Vocabulary Knowledge Scale" developed by Wesche and Paribakht (1996) was used in the research. The five-point rating figure and scoring scheme was taken by Ateş and Sis (2016). As a result of the study, the effect of giving/not giving example stereotyped phases on interpreting fossil words was examined, and it was observed that the participants had higher levels of interpretation of fossil words when they were given the example stereotyped phrases. Unearthing the fossil words is significant since it is considered as a building stone which will contribute to the development of the language having term problems and lacking to find equivalents of foreign words.
\end{abstract}

Keywords: vocabulary, idioms, reduplications, fossil words, archaic words

\section{INTRODUCTION}

Language is the key element that enables communication among people from past to present. It is a cultural entity whose foundations have been laid off in unknown times and have developed along with humanity. It has taken an important place in the life of a society and has been a memory of that society in its historical journey. It has lived, changed and developed with its society. Thus, it has become a common property of a society. The society's level of development influenced the language or vice versa.

Throughout the history, Turks established one of the ancient civilizations that existed on the world (Gumilev, 2002). Turkish which emerged and developed in the formation of this civilization is regarded as an ancient language. The historical records of Turkish such as Orhon and Uighur Inscriptions and findings on the historical Chinese sources

Citation: Direkci, B. (2019). Examination of Pre-service Teachers' Interpretation Case of Fossil Words in Turkish Reduplications/Idioms. International Journal of Instruction, 12(1), 1157-1172. https://doi.org/10.29333/iji.2019.12174a 
show that it has a wide vocabulary that dates back thousands of years (Aksan, 2011).

When various language elements from the oldest periods to present are examined, it is seen that Turkish has a sophisticated conceptualization capacity and a wide vocabulary that can even name the detailed-concepts. It can be state that Turkish which has spread to a wide geographical area with its historical depth, is enriched in vocabulary that much (Aksan, 2005).

The languages may change, evolve or even disappear over time together with the societies in which they exist. It is inevitable that the vocabulary is also influenced by this change. As these changes have emerged as new words, some words are forgotten and become obsolete over time as their use decreases. These types of changes occasionally occurred in either structure or meaning. Within these changes, the structural entity can be seen in the basic meaning of the verbal entity, which has the possibility of continuing its existence in the variants of the language as much as the day-to-day history of the language. According to Saussure (1916), in accordance with the principle of changeability of indicators, it can be seen that there are words capable of surviving in the basic sense even if they are subjected to small structural changes in long historical periods and in wide geographical regions (cited in Vardar, 1998). The presence of such words in the Turkish language is also striking. These words, the heritage of the language, can survive to this day, sometimes in isolation, sometimes in their stereotyped phrases.

Language is a social phenomenon. The events that the society has witnessed from past to present not only change the structure of society but also bring about changes in language in terms of sound, form and meaning depending on the factors such as the time, geography or cultural interaction etc. Language has emerged in societies and has been paralleled by the social line of life. A change is expected in such a language like Turkish which carried on in a wide geographical region with different branches for years. However, besides the changes, the language preserves some of the characteristics of the old times.

It is necessary to examine the language with a diachronic viewpoint in order to recognize and understand the changes it has faced from time to time in the historical course and to recognize the characteristics that have been preserved from the past. The phrases preserved from time immemorial are called "arkaizm", "eskililik", "eskil biçim", "eskicil öge" etc. in Turkish (Güneş, 2013). Turkish Language Association (TDK) does not include the word "eskicil" in its Turkish dictionary. Alternatively, it includes the French word "archaic" and defines it as follows: "The one which has become obsolete in the spoken and written language (archaic word or idiom)" (TDK, 2009)

Archaic language elements preserve their existence from the past to the present day in proverbs, idioms, reduplications, Turkish poems, lullabies, turkus, and riddles; they usually emerge in anonymous times and have been kept alive from past to today. In this struggle for existence, it appears that the elements of archaic language, especially when stereotyped, can protect itself against change (Maden \& Demir, 2017). There are many social, geographical and cultural aspects of the archaic language elements as well as the 
way in which they transmit to the future by preserving certain words of the period they emerged in.

The stereotyped phrases like idioms and reduplications are the key patterns that constitute the vocabulary. When the speech elements of these stereotyped phrases are examined, the presence of the structures showing the riches and delicacies of the language attracts attention. It is also a practical area for research in terms of the archaic words they have and are still in use today, as well as the old elements of speech.

Günay (2007) defines the idiom as follows: "The stereotyped phrases used in a sense other than their own meaning are called idioms." Idioms are stereotyped phrases that have their own form, the words cannot be changed. Even if it is a synonym, it cannot be expressed in another word. This formation, which takes place in terms of both form and meaning, occurs for many years through the language process of a society. It is only with the approval of the society to put a different meaning or say in a different form to the stereotyped phrase (Bilgin, 2006). "Idioms give us clues about the ways of expressing a language, the past of the language, the way of life, traditions and various characteristics. They are the most basic unit of language-based heritage "(Kara et al., 2006). Every idiom can be regarded as a track belonging to the community that has been placed on the history page for society.

Reduplications are also used with names such as "söz tekrarl", "ikizleme", "tekrarlar", "söz koşması" and "hendiadyoin" in Turkish. According to Bilgin (2006), reduplication is the repetition of a word or side by side use of the words which are homonyms, antonyms or have sound resemblances in order to strengthen the meaning." The most common and most typical characteristic of all dialects of Turkish in every period of history is the frequent occurrence of reduplications (Aksan, 2010). They are frequently used from past to present so as to use the language effectively, to provide languagespecific opportunity and power (Aksan, 2005). The reduplications which have a crucial place in Turkish vocabulary, add a different richness to the language, a distinct harmony and a rhythmic feel to the words.

The stereotyped phrases build a bridge between past and present. In time, while some words and phrases fall from their single usage for different reasons, others maintain to survive in stereotyped phrases (Türk, 2009). When a research is conducted from this point of view, it is possible to see some words which are either forgotten, discredited or discarded in the vocabulary of the language. These words, which try to maintain their existence from the old pages of history to the day-to-day, are called "fossil words" (Çolak, 2017). The fossil words are the words that are used singly in the past or in the dialects of the language, but nowadays there is little or no single usage in the standard language for different reasons. The stereotyped phrases such as proverbs, idioms, and reduplications constitute a living space for fossil words.

Within the vocabulary of a language, the speakers of the language create their own vocabulary in coordination with their lives and fund of knowledge. The vocabulary is the amount of words an individual has, the syntactic forms he uses to express himself correctly, his past experiences, or the semantic richness he has developed on ideas and 
concepts (Deshler at al., 2008, cited in İlter, 2015). The stereotyped phrases such as proverbs, idioms and reduplications play a crucial role in creating the vocabulary. Even in everyday life, the words are frequently used for different purposes and in different structures within different word groups, apart from their true meaning. In these usages, the stereotyped phrases are commonly used.

Vocabulary plays a crucial role in using basic language skills (receptive and productive). Hence, vocabulary teaching should be more emphasized in the course of learning and teaching (Göçer, 2009). The researchers who carried out studies on the vocabulary teaching clearly acknowledged that the vocabulary knowledge is the foremost factor in conceptual achievement and reading comprehension (La Flamme, 1997; Simpson at al., 2004; Marzano, 2004; Southerland, 2011). In order to achieve this success, the structure of the stereotyped phrases and words should also be recognized.

The idioms and reduplications are the patterns which have a significant place in vocabulary elements due to adding fluency, vitality and richness to the language are often used in written and verbal expressions. These patterns have come up to date from the past with their stereotyped phrases and delicacies of the language are ideally carried through them.

The presence of the archaic elements and fossil words used with the stereotyped phrases in the vocabulary of the individuals and maintaining their existence as a rich language are closely related to hand down the next generations, thereby the mother tongue education. According to İbe-Akcan (2014), Turkish textbooks which are used as the main sources in schools are inadequate in terms of vocabulary teaching. These inadequacies also affect the communication skills of the individuals and the development of language. Having rich or poor vocabulary knowledge is one of the variables that affects an individual's receptive and productive skills and influences the communication process. Rich vocabulary knowledge also includes proverbs, idioms and phrases in the learning contexts and in real life as well as single words. In order to acquire such vocabulary knowledge, the teachers should promote vocabulary learning process with different materials in accordance with the context and objectives as well as the textbooks (Karatay, 2007).

The fossil words that exist in Turkish vocabulary but continue to be used in stereotyped phrases rather than singularly, are significant in terms of showing the richness of our language. This study is noteworthy since it depicts the clear-cut picture of the vocabulary elements that are considered to have disappeared and investigates interpretation and usage status of fossil words. The pre-service Turkish language teachers were selected for the research since they are regarded as transmitters of language and culture. Conducted with the pre-service teachers who had training in language and literature, the present study is one of the few practical studies on this subject. For this reason, it is thought that the present study will make a significant contribution to the field.

\section{Purpose of the study}

The purpose of the study is to reveal pre-service Turkish language teachers' 
interpretation case of fossil words in Turkish reduplications and idioms. The research problems serve the purpose as follows:

1. To what extent do pre-service Turkish language teachers interpret fossil words in Turkish reduplications/idioms?

2. How do pre-service Turkish language teachers use fossil words in context?

Descriptive results will be sought in order to reveal interpretation case of fossil words through detailed findings and discussion on those findings.

\section{METHOD}

\section{Research Design}

The present study adopted concurrent triangulation design of mixed methods research. In this design, quantitative and qualitative data are concurrently collected and analysed. The priority is equal to both data types. While the data are generally analysed separately, they are combined or compared during the interpretation of the data. It is used as a model when a study utilizes two different methods (quantitative and qualitative) in an attempt to attest, cross check, or strengthen finding within the framework of a single study (Creswell, 2003; Morgan, 1998; Steckler, McLeroy, Goodman; Bird, \& McCormick, 1992).

\section{Population and Sampling}

The population consists of the pre-service Turkish language teachers and students who are studying at private and state universities in Turkey. Since it is not possible to reach the whole population, a sampling was selected for the research. Collecting the data through sampling provides some convenience for the researchers such as using much fewer human resources and financial resources, collecting the data in a shorter time (Büyüköztürk et al., 2014). The sample of the research consists of 168 pre-service teachers $(95=$ female, $73=$ male) who are studying in the Department of Turkish Language Teaching during 2017-2018 academic year at a state university. Regarding the objective of the study, the criterion sampling technique which "involves selecting cases that meet some predetermined criterion of importance" (Patton, 2001:238) was used to determine the study group.

\section{Data Collection Tools}

"Vocabulary Knowledge Test" developed by Wesche \& Paribakht (1996) was used as a data collection tool. It was administered to 4th grade students within the framework of a study entitled "The Investigation of the Effects of Frayer Model on Vocabulary Knowledge in Social Studies" by İlter (2015) and adopted into Turkish by Ateş \& Sis (2016) within the study "Adaptation of Vocabulary Knowledge Scale for Teaching Turkish as a Second Language". The scale can be used to test vocabulary knowledge capacity and to determine the meanings that are derived from words. It is possible to test vocabulary, grammar and semantic knowledge of the participants and to determine their ability to use the words in a sentence (İlter, 2015). The scale is used from one to five- 
point rating forms in the literature. The five-point rating figure and scoring scheme taken from Ateş \&Sis (2016) was selected for this research.

\begin{tabular}{|l|l|l|}
\hline Self-evaluation statements & Relationship & Score Interpretations \\
\hline $\begin{array}{l}\text { 1. I do not remember having seen the } \\
\text { word before. }\end{array}$ & & 1. The word is not familiar at all. \\
\hline $\begin{array}{l}\text { 2.I have seen it before, but I do not know } \\
\text { its meaning }\end{array}$ & & $\begin{array}{l}\text { 2. The word is familiar but its meaning is not } \\
\text { known. }\end{array}$ \\
\hline $\begin{array}{l}\text { 3. I have seen it before, I guess it } \\
\text { means... (synonym or translation) }\end{array}$ & & $\begin{array}{l}\text { 3. A correct synonym or translation of the } \\
\text { word is given. }\end{array}$ \\
\hline $\begin{array}{l}\text { 4. I know the word. It means.... } \\
\text { (synonym or translation) }\end{array}$ & $\begin{array}{l}\text { 4. The word is correctly used in a sentence in } \\
\text { terms of semantical aspect. }\end{array}$ \\
\hline $\begin{array}{l}\text { 5. I can use the word in a sentence. (If } \\
\text { you do this section, please also do } \\
\text { section IV) }\end{array}$ & $\begin{array}{l}5 \text {. The word is correctly used in a sentence in } \\
\text { terms of semantical and grammatical aspects. }\end{array}$ \\
\hline
\end{tabular}

Figure 1

Vocabulary knowledge scale and scores

Ateş \& Sis (2016)

"The scale is scored as follows:

- The student will get 1 point when s/he states "I do not remember seeing the word before." This point refers that the word is not familiar at all.

- The student will get 2 points when s/he states "I have seen it before, but I do not know what it means". It informs that while the word is familiar, the meaning is not known.

- The student will get 3 points when s/he states "I have seen it before, I guess it means... (synonym or translation) and writes the synonym or the translation of the word in his/her language.

- The student will get 2 points when s/he writes an incorrect synonym or translation. It is interpreted that the student has seen it before but does not know its meaning.

- If the student writes a correct synonym or translation to the section " I know the word. It means.... (synonym or translation)", s/he will get 3 points. The important thing here is whether the student is sure of himself. If s/he writes a wrong synonym or translation, s/he will get 2 points.

- It is expected the student to write a sentence when s/he chooses the section "I can use the word in a sentence. (If you do this section, please also do the section 4)" The student will get points according to the level of error of his/her sentence. If the sentence is appropriate to the semantic and grammar of Turkish, s/he will get 5 points. If the student makes a mistake in the target word or phrase in the sentence and uses the word correctly in this sentence, s/he will get 4 points. 4 points refer that the sentence is not completely appropriate in terms of grammar accuracy. If both semantic and grammatical mistakes are made, but the synonym or translation is correct, s/he will get 3 points.

If the sentence contains both semantic and grammatical errors and at the same time synonym or definition of the target word/phrase cannot correctly be written, s/he will get 2 points (Ateş \& Sis, 2016). 
Since the scale was not used at university level in Turkish before, it was piloted to 42 participants and asked for expert's review. Once it was agreed that it is comprehensible and practicable, it was administered to the sampling. As a result of the reliability and validity analysis, the internal consistency coefficient of the scale was determined as .925 .

\section{Data Collection Process}

The researcher reviewed the relevant literature in order to determine fossil words to be used in the study. In this regard, the study entitled "Fossil Words in Turkish" by Çolak (2015) was taken as a reference. Since Çolak conducted a large-scale study by performing a content analysis for Turkish National Corpus of 50 million words (created after collecting texts after the year 1990 in Mersin University). The analyses in the corpus show that fossil words are not usually in singular form but in stereotyped phrases. In his study, Çolak also gave information regarding the use of fossil words alone and in stereotyped phrases and the frequency of using in a sentence (see Appendix 1). A total of 75 fossil words $(50=$ reduplication, $25=$ idiom) specified in the study of fossil words in Turkish were determined to be used for the research.

75 fossil words determined by Vocabulary Knowledge Scale were combined to create "Vocabulary Knowledge Form for Fossil Words". Since it was hypothesized that the levels of interpretation would be different when the words are given in singular form or stereotyped phrases, two forms were prepared for the participants. While the words were given in singular in the first form, the most common stereotyped phrases were integrated into the words in the second form.

While administering the form, the participants were asked to choose the appropriate phrase for fossil words and to make sentences related to the context when they feel they know the meaning of the word. The forms were randomly handed out to the participants and each participant filled only one form.

\section{Data Analysis}

The values of skewness and kurtosis were checked in order to examine whether the data obtained from "Vocabulary Knowledge Form for Fossil Words" showed normal distribution. Tabachnick \& Fidell stated that data are normally distributed when the values of skewness and kurtosis are between +1.5 and -1.5 (Sevin \& Küçük, 2016). As seen in Table 1, the data show normal distribution since the values of skewness and kurtosis are between +1.5 and -1.5 .

Table 1

Skewness and kurtosis values of data

\begin{tabular}{lll}
\hline Measure & Value & SE \\
\hline Skewness & -.45 & .18 \\
Kurtosis & -.37 & .37 \\
\hline
\end{tabular}

Since the test of normality results attest that the collected data shows normal distribution, parametric statistical tests were used to examine interpretation case of the fossil words. 
The analysis results show that there is not a significant difference for interpreting the fossil words in terms of gender $(\mathrm{F}, \overline{\mathrm{X}}=191,7-\mathrm{M}, \overline{\mathrm{X}}=187,1)$. The changes in the level of interpreting the words between studying them alone and giving them with example phrases were also examined. In addition, the use of the fossil words in a sentence by the participants in the Vocabulary Knowledge Form for Fossil Words was pointed out so that the interpretation cases of the fossil words were examined thoroughly. The sentences were examined semantically, and it was tried to discover the reasons for making mistakes. Besides, it was checked whether the participants used the words in the sentence alone or with a stereotyped phrase.

\section{FINDINGS}

In this part, the findings obtained through the analysis of the collected data will be presented. They are grouped under four headings:

\section{Findings on the levels of interpreting the fossil words across the groups}

t-test was computed in order to examine interpretation case of fossil words. Table 2 gives the t-Test results for comparing the levels of interpreting the fossil words of the participants who were/were not given a stereotyped phrase.

Table 2

t-test results of levels of interpreting the fossil words according to the cases where the example stereotyped phrase was/was not given

\begin{tabular}{lllllll}
\hline Example & $\mathrm{N}$ & Mean & SD & T & Df & P \\
\hline Yes & 82 & 179.09 & 34.30 & -4.21 & 166 & .000 \\
No & 86 & 200.19 & 30.51 & -4.20 & 161.64 & \\
\hline
\end{tabular}

According to the t-test results, it was observed that there was a significant difference between the mean scores of the participants who were given the words with the stereotyped phrases and the ones who were given the words alone. While the mean score of the first group was $\bar{X}=200,19$, it was $\bar{X}=179,09$ for the second group.

In Table 3, while there is a significant difference in the group in which the example stereotyped phrases are given for the items Q4, Q6, Q7, Q9, Q10, Q11, Q12, Q13, Q24, Q27, Q37, Q40, Q41, Q43, Q46, Q4, Q48, Q51, Q52, Q53, Q54, Q55, Q56, Q57, Q 59, 61, Q62, Q63, Q64, Q69, Q70, Q72, Q73, Q75, there is not a significant difference for the items Q1, Q2, Q3, Q5, Q8, Q14, Q15, Q16, Q17, Q18, Q19, Q20, Q21, Q22, Q23, Q25, Q26, Q28, Q29, Q30, Q31, Q32, Q33, Q34, Q35, Q36, Q38, Q39, Q42, Q44, Q45, Q49, Q50, Q58, Q60, Q65, Q66, Q67, Q68, Q71, Q74.When the table is examined on the basis of the average scores of the fossil words, it is seen that interpretation level of the words " derli, gidım, tıklım, abuk " is the highest in both groups.

\section{Findings on the levels of interpreting the fossil words across the groups}

Since the forms administered to the participants were different, there were statistically significant differences across the groups in terms of interpretation levels. On the other hand, while the example stereotyped phrases increased the level of interpretation in some words, it appears that in some cases either it had an opposite effect or it did not affect. Information on these findings is presented in Tables 4, 5, and 6. 
Table 3

Words having the most significant increase in the level of interpretation when the $\underline{\text { stereotyped phrases are given as an example }}$

\begin{tabular}{lllll}
\hline \multirow{2}{*}{ Fossil word } & $\begin{array}{l}\text { Stereotyped phrase } \\
\text { given as an example }\end{array}$ & $\begin{array}{l}\text { (Example } \\
\text { given) } \\
\overline{\bar{X}}\end{array}$ & $\begin{array}{l}\text { (Example not } \\
\text { given) }\end{array}$ & Variance \\
\hline Apış- & Apışık kalmak & 3.18 & 1.84 & 1.34 \\
Salık & Salık vermek & 2.30 & 0.99 & 1.31 \\
Pus- & Sus pus & 3.33 & 2.11 & 1.21 \\
Kargacık & Kargacık burgacık & 2.57 & 1.43 & 1.14 \\
(Kargaşık) & & & 1.05 & 1.13 \\
Çakır & Çakırkeyif olmak & 2.18 & 1.84 & 1.12 \\
Hır & Hır çıkarmak, hır gür & 2.96 & 1.13 & 1.09 \\
Çala & Çalakalem, çalakaş1k & 2.22 & 1.97 & 1.02 \\
Bet(1) & Beti benzi atmak & 2.99 & 0.89 & 1.01 \\
Sepken & Sulu sepken & 1.91 & 1.41 & 1.01 \\
Bet(2) & Beti bereketi kaçmak & 2.42 & & \\
\hline
\end{tabular}

Table 3 illustrates 10 words whose level of interpretation has showed the highest increase in mean values when the stereotyped phrases are given as an example. When these words are examined, it is seen that the words with the highest level of interpretation are apış-, salık, and pus-.

Table 4

Words having the same level of interpretation when the stereotyped phrases are given as an example

\begin{tabular}{|c|c|c|c|c|}
\hline Fossil word & $\begin{array}{l}\text { Stereotyped phrase } \\
\text { given as an example }\end{array}$ & $\begin{array}{l}\text { (Example } \\
\text { given) } \\
\overline{\mathrm{X}}\end{array}$ & $\begin{array}{l}\text { (Example not } \\
\text { given) } \\
\overline{\mathrm{X}}\end{array}$ & Variance \\
\hline Kuşam & Giyim kuşam & 3.04 & 2.95 & 0.08 \\
\hline Fink & Fink atmak & 2.07 & 2.01 & 0.06 \\
\hline Kacak & Kap kacak & 2.87 & 2.81 & 0.06 \\
\hline Çoluk & Çoluk çocuk & 2.57 & 2.51 & 0.05 \\
\hline Derli & Derli toplu & 3.71 & 3.67 & 0.04 \\
\hline Karman & Karman çorman & 3.06 & 3.03 & 0.02 \\
\hline Tefek & Ufak tefek & 2.30 & 2.27 & 0.02 \\
\hline Yordam & Yol yordam & 2.79 & 2.77 & 0.02 \\
\hline Dolan & Yalan dolan & 2.89 & 2.93 & -0.04 \\
\hline
\end{tabular}

Table 4 presents the words which do not have significant difference $(p>0,1)$ in terms of interpretation level when the example stereotyped phrases are/are not given. These words are the followings: kuşam, fink, kacak, çoluk, derli and karman. 
Table 5

Words having the lower level of interpretation when the stereotyped phrases are given as an example

\begin{tabular}{lllll}
\hline \multirow{2}{*}{ Fossil word } & $\begin{array}{l}\text { Stereotyped phrase } \\
\text { given as an example }\end{array}$ & $\begin{array}{l}\text { (Example given) } \\
\text { X }\end{array}$ & $\begin{array}{l}\text { (Example not given) } \\
\text { Pariance }\end{array}$ \\
\hline P1rtı & P1lı pırtı & 1.48 & 2.30 & -0.81 \\
P1lı & P1lı pırtı & 2.44 & 2.92 & -0.48 \\
Börtü & Börtü böcek & 2.41 & 2.71 & -0.30 \\
Kubidik & Abidik kubidik & 1.90 & 2.20 & -0.29 \\
Bullak & Allak bullak & 2.56 & 2.82 & -0.26 \\
Pot & Pot kırmak & 2.51 & 2.77 & -0.25 \\
Sabuk & Abuk sabuk & 2.20 & 2.43 & -0.22 \\
Pirtık & Yirtı pirtık & 2.41 & 2.62 & -0.20 \\
Gidım & Gidım gidım & 3.63 & 3.83 & -0.19 \\
Süklüm & Süklüm püklüm & 1.43 & 1.55 & -0.11 \\
\hline
\end{tabular}

Table 5 shows 10 words whose interpretation level showed the greatest decrease in mean values when the stereotyped phrases are given. They are the followings: pirt1, pill, and börtü. When the findings are taken into consideration, it is seen that the type of words are either noun or noun-origin. While these words are interpreted, the participants who filled the form consisting of the example stereotyped phrases remain in between the word's own meaning and more widespread stereotyped usage (see Appendix 1), the examples lead to misconceptions and have an adverse effect on the mean scores.

\section{Findings on the pre-service teachers' semantically incorrect use of fossil words} in the sentence

In order to analyse the fossil words from the semantic aspect, the sentences made by the participants were examined. In these sentences, while they sometimes used them correctly, they occasionally misused them. When we examine the sentences consisting of this misunderstanding, two fundamental mistakes are made. These can be expressed as "making mistakes by using the meaning of the stereotyped phrases" and "using it out of its own meaning (single or phrase)". Since there were two different forms administered to the participants, the semantic errors of the participants who filled out the forms with the stereotyped phrases were analysed in detail. Details are presented in Table 6. 
Table 6

Frequency values for the semantic misuse of fossil words in a sentence

\begin{tabular}{|c|c|c|c|c|c|}
\hline \multirow[t]{3}{*}{ Word } & \multicolumn{4}{|c|}{ Reason of error } & \multirow[t]{3}{*}{ Total } \\
\hline & \multicolumn{2}{|c|}{ Meaning of Stereotyped Phrases } & \multicolumn{2}{|c|}{ Use of Words out of Its Meaning } & \\
\hline & $\begin{array}{l}\text { Example } \\
\text { given }\end{array}$ & $\begin{array}{l}\text { Example not } \\
\text { given }\end{array}$ & $\begin{array}{l}\text { Example } \\
\text { given }\end{array}$ & $\begin{array}{l}\text { Example not } \\
\text { given }\end{array}$ & \\
\hline Kolaçan & 5 & 4 & 13 & 27 & 49 \\
\hline Çoluk & 9 & 11 & 12 & 14 & 46 \\
\hline Çakır & 3 & 1 & 10 & 30 & 44 \\
\hline İncik & 5 & 1 & 10 & 23 & 39 \\
\hline Biçki & 4 & 4 & 6 & 17 & 31 \\
\hline Tiris & 8 & 6 & 5 & 9 & 28 \\
\hline Bark & 7 & 4 & 5 & 8 & 24 \\
\hline Tük & 7 & 13 & 3 & 1 & 24 \\
\hline $\operatorname{Bet}(1)$ & 4 & 1 & 5 & 13 & 23 \\
\hline Burgacık & 3 & 1 & 12 & 5 & 21 \\
\hline
\end{tabular}

Table 6 illustrates the most misused fossil words in terms of the semantical aspect and the type of errors. When they are used in a sentence, the words which had highest semantic mistakes are "kolaçan, çoluk and çakır". It was seen that using the words out of its own meaning (single or phrases) is the primary reason of the semantical errors. The reason behind this error can be that the participants tried to interpret them by guessing since they either fell into oblivion or were little known. Table 7 also shows that the participants has a smaller number of errors when they are given the example stereotyped phrases. It can be thought that it is easier to interpret the rare word when the daily-life usage forms are given as an example. Another remarkable point in the table is that "burgacik" fossil word caused the higher errors when it was given with an example stereotyped phrase than the single form.

\section{Findings on the usage patterns of fossil words in the sentences}

In the forms, the participants were asked to use the fossil words in a sentence. While some could not make a sentence about the words falling into oblivion, others could use them singly by guessing or knowing their meanings. The third group could use them in a sentence within the stereotyped phrases used today. These three different cases are shown in Tables 7, 8 and 9 below.

Table 7

Frequency values for cases where fossil words cannot be used in a sentence

\begin{tabular}{llll}
\hline Word & Example given & Example not given & Total \\
\hline Saraka & 78 & 82 & 160 \\
Yapıldak & 74 & 76 & 150 \\
Sökün & 70 & 73 & 143 \\
Icık & 65 & 75 & 140 \\
Sepelek (Semelek) & 63 & 76 & 139 \\
Sepken & 61 & 76 & 136 \\
Çala & 59 & 72 & 131 \\
Cicık & 50 & 76 & 126 \\
Salık & 58 & 62 & 120 \\
Süklüm & 60 & 58 & 118 \\
\hline
\end{tabular}


When Table 7 is examined, we see the fossil words which the participants made at least sentences when they were asked to make sentence. They are listed as "saraka, yapdak and dismantı". When the table is examined in general, it is noteworthy that the number of sentences related to the fossil words decreases when the stereotyped phrase of the fossil words is not given as an example.

Table 8

Frequency values for the cases where fossil words are singly used in a sentence

\begin{tabular}{llll}
\hline Word & Example given & Example not given & Total \\
\hline Alavere & 2 & 19 & 21 \\
Biçki & 2 & 18 & 20 \\
Çil & 2 & 14 & 16 \\
Çakır & 1 & 13 & 14 \\
Gıdım & 3 & 9 & 12 \\
\hline
\end{tabular}

Table 8 ranks the fossil words which are commonly used in a sentence with single form based on the frequency values. Accordingly, the words "alavere, biçki, çil, çakır and gidım" become prominent as singly-used fossil words in a sentence. The notable detail in the table is that using the commonly used fossil words singly rather than accompanied with stereotyped phrases enabled them to be used in the sentence. These words are known by the participants at the level that can be used in a sentence without giving example phrases. We observe that some fossil words can be used alone, apart from the occasional phrase form. It can be assumed that this situation overlaps the meaning of the word and the phrase form or if it is homonym, the fossil words do not mislead.

Table 9

Frequency values for the cases in which fossil words are used with the stereotyped phrases in a sentence

\begin{tabular}{llll}
\hline Word & Example given & Example not given & Total \\
\hline Abuk & 79 & 70 & 149 \\
Didik & 79 & 70 & 149 \\
Aval & 80 & 65 & 145 \\
Alavere & 77 & 68 & 145 \\
Derli & 75 & 68 & 143 \\
Allak & 78 & 64 & 142 \\
Abidik & 76 & 64 & 140 \\
Apar & 79 & 61 & 140 \\
\hline
\end{tabular}

Table 9 ranks the frequency values of the most commonly used fossil words that were used in the sentences of the participants with the stereotyped phrases. Accordingly, these words are ranked as "abuk, didik, aval, alavere, derli ..." It was observed that when the example phrases were given, the participants used them in the sentences with either the same or similar examples. An increase was observed in interpreting the fossil words when they were given together with the example stereotyped phrases. The reason behind this finding is that the participants had examples with the words and phrase forms are well-known today and they continue to be used in the form of the phrases. 


\section{DISCUSSION AND RECOMMENDATION}

The pre-service Turkish language teachers' interpretation case of fossil words in Turkish reduplications and idioms were examined in this study. Accordingly, it is revealed that the gender variable does not show any significant difference. It is seen that example stereotyped phrases are effective in the interpretation of fossil words. When the use of fossil words in sentences is examined, it can be said that the stereotyped phrases given as an example increase the usage of the fossil words.

It was also observed that the participants filling the form with the example stereotyped phrases had higher levels of comprehending the fossil words. With this result, it can be said that the pre-service teachers utilize example stereotyped phrases so as to interpret the fossil words. This finding shows similarity with the study of Çolak (2017) who found that there were fossil words maintaining their existence through either in the phrases or less/no used singly out of the phrases. Çoçuk (2012) also concluded that the pre-service teachers had low-level predictions on the idioms semantically.

When examining the semantic incorrect use of the fossil words in a sentence, two kinds of reasons for making mistakes were observed. They can be classified as "making mistakes by using the meaning of the stereotyped phrases" and "using the word out of its own meaning (single or phrases)". As a result of using a word out of its own meaning, the semantical errors were observed. In addition, the number misinterpreting the fossil words with the example stereotyped phrases is higher than the ones without examples. Therefore, it can be stated that the misinterpreting case is increased when the meaning of the fossil words is tried out or used other than the stereotyped phrase.

When we have a look at the use of the words in the sentence, it draws our attention that the pre-service teachers had difficulty in making sentences with the fossil words. It was seen that the participants failed to use some fossil words in sentences or attempted to use them alone. It was also precipated that while the pre-service teachers failed to use the fossil words in a sentence with their single meaning, they succeeded in making sentences with the stereotyped phrases of the words.

It should not be forgotten that like fossil words, archaic words and other language elements which are no longer in use are also the linguistic richness of a language. The languages naturally undergo a change and renew over time. However, this change and renewal should not destroy the language elements that are based on very old traces and increase the functionality of the language. These language elements and archaic words can be reintroduced into the language only through education. However, there is not an established system of vocabulary teaching in mother-tongue education. In their studies, İbe-Akcan (2014) stated that the target words that were supposed to be unknown and learned in the workbooks were randomly selected for Turkish textbooks. Besides, Gündoğdu's study (2012), in which examined vocabulary teaching activities in 6th grade Turkish textbook, revealed that the workbook did not include proverbs, stereotyped phrases and reduplication examples. Taking into consideration these negative findings, Turkish and Literature textbooks and workbooks can be prepared in a way that will cover commonly used stereotyped phrases. In addition, appropriate books in accordance 
with the levels can be selected and they may embody reading list and activities integrated into the learning period. Since the single meaning of the fossil words are less known, vocabulary guessing, and brainstorming techniques can be used in the framework of the semantical relationships for more effective and enjoyable learning. In line with the objective of the course, specific materials such as cartoons and digital contents can be used in these activities.

As a result, it can be concluded that the fossil words showing the archaic features have been transferred from the beginning to the present day in a stereotyped form and continues to be used within the stereotyped phrases today. The results of Maden \& Demir's study (2017) concluded that the meanings of the old words given in stereotyped phrases must be known and used to enrich individuals' vocabulary. Unearthing stereotyped phrases such as idioms and proverbs, knowing that they mean, an increase in the use of those words will enrich the language, which currently has terminology problem and lacks finding the equivalents of foreign words, and improve the vocabulary of the language. Since there are only few practical studies in this regard, the present study will give suggestions for further studies and a possible comparison with further studies' results will contribute to the literature.

\section{REFERENCES}

Aksan, D. (2005). Türkçenin zenginlikleri incelikleri [Richness and delicacies of Turkish] ( $1^{s t} E d$.). Bilgi Yayınevi, Ankara.

Aksan, D. (2010). Türkiye Türkçesinin dünü, bugünü, yarını [Past, present and future of Turkish] (6 $6^{\text {th }}$ Ed.). Bilgi Yayınevi, Ankara.

Aksan, D. (2011). Tükçenin gücü [Power of Turkish] (13 ${ }^{\text {th }}$ Ed.). Bilgi Yayınevi, Ankara.

Ateş, A. \& Sis, N. (2016).İkinci dil olarak Türkçe öğretimi için kelime bilgisi ölçeği uyarlamas1 [Adaptation of vocabulary knowledge scale for teaching Turkish as a second language]. Turkish Studies International Periodical for the Languages, Literature and History of Turkish or Turkic, 11(19).

Bilgin, M. (2006). Anlamdan anlatıma Türkçemiz [Turkish: from semantics to discourse] (2 $2^{\text {th }} E d$.). An1 Yayınc1lık, Ankara.

Büyüköztürk, Ş., Çakmak Kılıç, E., Akgün, Ö. E., Karadeniz, Ş., \& Demirel, F. (2011). Bilimsel araştırma yöntemleri [Scientific research methods] ( $8^{\text {th }}$ Ed.). Pegem A. Yayıncilık, Ankara.

Creswell, J. W. (2003). Research design: Qualitative, quantitative, and mixed methods approaches (2nd ed.). Thousand Oaks, CA: Sage.

Çocuk, H.E. (2012). Öğretmen adaylarının deyimleri anlamsal açıdan tahmin edebilirlikleri: Mersin Üniversitesi örneği [The pre-service teachers' prediction of idioms in terms of their meaning: Mersin university case]. Mersin Üniversitesi Ĕgitim Fakültesi Dergisi, 8(2), 46 -55.

Çolak, G.(2017). Türkçede fosil kelimeler [Fossil words in Turkish] (2 $2^{\text {th }}$ Ed.). Bilge 
Kültür Sanat, İstanbul.

Deshler, D. D., Palincsar, A. S., Biancarosa, G., and Nair, M. (Eds.). (2008). Informed choices for struggling adolescent readers: A research-based guide to instructional programs and practices. Ny, International Reading Association, New York.

Göçer A. (2009). Türkçe eğitiminde öğrencilerin söz varlığını geliştirme etkinlikleri ve sözlük kullanımı [Activities of developing vocabulary of students and dictionary usage in Turkish education]. Turkish Studies International Periodical for the Languages, Literature and History of Turkish or Turkic, 4(4).

Gumilev, L. N. (2002). Hunlar [Huns]. Ahsen Batur Selenge Yayınları, İstanbul.

Günay, D. (2007). Kelime bilime giriş [Introduction to lexicology]. Multilingual Baskı, İstanbul.

Gündoğdu, A. E. (2012). İlköğretim altıncı sınıf Türkçe dersi sözcük öğretimi etkinliklerinin çeşitli değişkenler açısından incelenmesi [Investigation of vocabulary teaching activities in sixth grade levels of primary school Turkish lesson student workbook]. Uluslararası Türkçe Edebiyat Kültür Eğitim (TEKE) Dergisi, 1(1), 201217.

Güneş, B. (2013). "Valeh Hacılar'ın dilinde arkaik sözler" [The archaic words in Valeh Hacilar's language]. Uluslararası Türkçe Edebiyat Kültür Eğitim Dergisi, 2(4),116-130.

İbe Akcan, P. (2014). Türkçe öğretiminde sözcük etkinlikleri: İlköğretim 1.-5. sınıf düzeyinde alıştırmalara ilişkin bir çözümleme [Vocabulary activities in Turkish language teaching: an analysis of the exercises in the 1st -5th level student books] . Dil ve Edebiyat Dergisi / Journal of Linguistics and Literature, 11(2), 43-67.

İlter, İ. (2015). Sosyal bilgilerde kelime hazinesinin geliştirilmesinde Frayer Modelinin etkisinin incelenmesi [The investigation of the effects of Frayer Model on vocabulary knowledge in social studies] . Illkögretim Online, 14(3), 1096-1129.

Kara, A. , Kayabaşı, B., Alkayış, M. F. (2006). İlköğretimde kullanılan deyimlere ilişkin bir araştırma [A study on idioms used in primary education] . Pamukkale Üniversitesi Eğitim Fakülte Dergisi, 20, 1-12.

Karasar, N. (1999). Bilimsel araştırma yöntemi: Kavramlar, ilkeler, teknikler [Scientific research methods: concepts, principles, techniques] $\left(9^{\text {th }} E d\right.$.). Nobel Yayınlar1, Ankara.

Karatay, H. (2007). Kelime öğretimi [Vocabulary teaching] . Gazi Eğitim Fakültesi Dergisi, 27(1), 141-153.

Laflamme, J.G. (1997). The effect of multiple exposure vocabulary method and the target reading/writing strategy on test scores. Journal of Adolescent and Adult Literacy, 40(5), 372-384.

Maden, S. ve Demir, R. (2017). Atasözlerindeki eskicil (arkaik) unsurlar [Archaic elements in proverbs] . Ana Dili Eğitimi Dergisi, 5(2), 189-200. 
Marzano, R. J. (2004). What works in schools: Translating research into action? Alexandria, VA: Association for Supervision and Curriculum Development, Printed in USA.

Morgan, D. (1998) "Practical Strategies for Combining Qualitative and Quantitative Methods: Applications to Health Research", Qualitative Health Research, 8, 362-376

Patton, M. Q. (2001). Qualitative research \& evaluation methods. (3rd ed.). Saint Paul, MN: Sage Publications.

Saussure, F. D. (1916). Genel dilbilim dersleri (çev: Prof. Dr. Berke Vardar, 1998) [Main linguistics courses]. Multilingual Yayınları, İstanbul.

Sevin, D. H. ve Küçük S. (2016). İşgörenlerin rekreasyonel etkinliklere katılım düzeyleri ile çalışma performansları arasındaki ilişkiyi belirlemeye yönelik bir araştırma [A theoretical study on workplace recreation: suggestion on its applicability in tourism enterprises]. Journal of Recreation and Tourism Research, 3 (1), 24-31.

Simpson, M. L., Stahl, N. A., and Francis, M. A. (2004). Reading and learning strategies: Recommendations for the 21st century. Journal of Developmental Education, $28(2), 15-32$.

Southerland, L. (2011). The effects of using interactive word walls to teach vocabulary to middle school students. (Unpublished Work). University of North Florida.

Steckler, A., McLeroy, K. R., Goodman, R. M., Bird, S. T., \& McCormick, L. (1992). Toward integrating qualitative and quantitative methods: An introduction. Health Education Quarterly, 19(1), 1-8.

Tabachnick, B.G., Fidell, L.S. (2013). Using multivariate statistics (6 ${ }^{\text {th }}$ Ed.) Pearson, Boston.

Türk Dil Kurumu (2009). Türkçe Sözlük [Turkish dictionary] (10 ${ }^{\text {th }}$ Ed.). TDK Yayınları, Ankara.

Türk, V. (2009). Türkülerde eski (arkaik) sözler [Archaic words in songs]. Turkish Studies International Periodical For the Languages, Literature and History of Turkish or Turkic, 4(8), 83-88

Vardar, B. (1998). Genel dilbilim dersleri [Main linguistics courses]. Multilingual Yayınları, İstanbul.

Weshe, M., \& Paribakht, T.S. (1996). Enhancing vocabulary acquisition through reading: A hierarchy of text-related exercise types. Canadian Modern Language Review, 52, 155-178. 